\title{
Feasibility study of biomass power plants fired with maize and sorghum stalk in the Sub-Saharan region: a case for the northern part of Cameroon
}

\author{
Alain Biboum ${ }^{1 *}$, Ahmet Yilanci \\ 'Graduate School of Natural and Applied Sciences, Solar Energy Science Branch, Ege University, Izmir, Turkey \\ ${ }^{2}$ Institute of Solar Energy, Ege University, Izmir, Turkey
}

ORCID: A. Biboum (0000-0001-5979-8094), A. Yilanci (0000-0001-9636-0264)

\begin{abstract}
This study is dealt with evaluation of energy potential of the crop residues for biomass power plants to produce electricity and thermal energy in the northern province of Cameroon. The proposed biomass power plants have open cycle electricity generation and steam extraction units for pre-treatment processes of dry agricultural residues and Organic Rankine Cycle (ORC) that converts low-temperature heat into electricity. Firstly, possible locations are assessed and determined by taking into consideration status of agricultural residues, transportation needs of the residues and demands for electricity and heat in the locations. Then, techno-economic analysis is done by focusing on municipalities in the departments of Faro, Mayo-Rey and Benue, which are respectively Poli, Bouki, Tcholleré, Toroua, Amdoumré and Tcheboa. The total investment cost is estimated to be 874.5 million USD for installed capacity of $270 \mathrm{MW}$ for the electricity needs of the above-mentioned municipalities. The levelized cost of electricity (LCOE) values are found to be the ranges from 6.81 USDcent/kWh to 12.9 USDcent $/ \mathrm{kWh}$. This study shows that Carbon bonus incentive with the value of 5.16 USDcent $/ \mathrm{kWh}$ for the biomass power plant would allow the realization of the projects in the indicated sites. Without the carbon bonus incentive, there will be a negative impact on the electricity generation capacity in the municipalities of Bouki and Tcholleré by causing losses of $72.778 \mathrm{GWh} /$ year and $137.331 \mathrm{GWh} /$ year, respectively. Moreover, the locations with the greatest investment potential are found as Bouki and Tcholleré for a payback period of around 6 years, and LCOE values are close to 6.81 USDcent $/ \mathrm{kWh}$ and 6.98 USDcent $/ \mathrm{kWh}$ for the biomass power plant fired with sorghum, respectively. It is observed that mixing the crop residues are not suitable for these sites. The municipalities of the city Benue have an estimated production potential of $636.6 \mathrm{GWh}$ for LCOE values between $7.66 \mathrm{USDcent} / \mathrm{kWh}$ and $8.20 \mathrm{USDcent} / \mathrm{kWh}$ with a payback period of less than 6.5 years.
\end{abstract}

Keywords: Biomass power plant, levelized cost of electricity, carbon bonus, payback period.

\section{INTRODUCTION}

Electricity and heat production, which is called cogeneration, from biomass power plants (BPPs) provide non-intermittent energy for industries and peoples. Also, waste heat can be used in various applications together with electricity in order to increase overall efficiency of the power plant. Cameroon, which is situated in the central region of Sub-Sahara Africa and opened to the Atlantic Ocean, has a large biomass potential estimated at 19 million hectares of forest covering three-quarters of its territory [1]. Agriculture is the principal key sector of the country's economy. This sector covers more than $30 \%$ of employment base (more than $60 \%$ unskilled workers), ensures national food security, and helps a great degree to the country's GDP [2]. The country mainly produces maize, cassava, banana, sorghum, rice, millet, wheat, sugarcane, cocoa, coconut, coffee and rubber [1]. Agricultural activities in Cameroon can be divided into five agro-ecological zones. The north region is one of these zones characterized by a high cereals production. The country uses biomass resources for heating and lighting needs for the majority of rural populations. Utilization of fruit bunches of palm oil, bagasse of sugarcane and stalk of maize are not significantly used to produce electricity throughout BPPs [3-5]. Actually, the overall capacity of BPPs in the food
${ }^{*}$ Corresponding authour

Email: biboumalain@gmail.com
European Mechanical Science, September 2019; 3(3): 102-111 doi: https://doi.org/10.26701/ems.493188

Received: December 7, 2018

Accepted: June 29, 2019 
industry sector is estimated above $13 \mathrm{MW}$ [6].

There are some studies on BPPs by utilizing the agricultural residues. Cheng et al. [7] developed a new methodology to analyse and evaluate potential of agriculture residues for a BPP. The proposed methodology analyses local status of residues, demand for multi-duty agricultural residues and logistics. Nunes et al. [8] conducted an investigation on current difficulties related to the utilization of residual forest stemming from forestry activities and wood wastes for BPPs. Malek et al. [9] did also an investigation of a BPP for supplying suitable and secure energy. They analysed $10 \mathrm{MW}$ biomass power plant using fruit bunch, mesocarp fibre, oil palm frond, oil palm trunk, palm kernel shell, and found out net present values, internal rate of return and payback period and system efficiencies of BPP. Additionally, Sampim et al. [10] presented a method called Fuel Switching Flexibility (FSF) method that can plan to handle with risks of biomass price fluctuations. The used method increases the financial values considerably. Gebreegziabher et al. [11] proposed a thermodynamic analysis of a biomass thermal power plant using empty fruit brunches as a primary energy source to improve the design, environmental impact and efficiency of power plant. The results of this study showed that the overall efficiency of BPP can be improved by adding drying and heat integration units. Kalina [12] studied a small-scale biomass power plant with Organic Rankine cycle. The author developed models of the system which can give the estimated values of power and energy efficiency. Furthermore, in another paper, an investigation of rice straw potential for electricity generating in Egypt was presented by Abdelhady et al. [13]. The results indicate that 3.1 million tons/year of rice straw can provide annual net output electricity of 2,447 $\mathrm{GWh}$, and can contribute to decrease $\mathrm{CO}_{2}$ emissions with approximately 1.2 million tons $\mathrm{CO}_{2}$ per year. Ali et al. [14] investigated the comparative potential of different power generation systems including natural gas, coal combustion with and without exhaust gas recirculation (EGR), pulverized supercritical coal and biomass-fired power plant. The authors said that BPP with $\mathrm{CO}_{2}$ capture and compression results a decrease in emissions.

The current study has particular interests for the issues of electrification and the utilization of local energy resources in rural and urban areas in Cameroon. Electrification is a paramount issue in Cameroon, but specifically in the regions of eastern and northern Cameroon. The access to electricity is about $50 \%$ in urban areas against less than $10 \%$ in rural areas, which is a significant threat to the economy and the population's life. The regions that suffer the most from a lack of electrification are Adamawa, East, Far North and North, where the rate of electricity access is $10 \%$ among the poor and 33\% among non-poor populations [4-5].The interconnected electrical grid in the eastern region is less than 7\%, and it is essentially made up of isolated thermal power stations supported by approximately 30 distribution systems. The interconnected grid in the northern region accounts for over $10 \%$ of total electricity generation. The northern region is one of the regions that is currently experiencing the greatest demographics. Furthermore, this work will provide thermal energy by converting heat losses into useful energy for residential, industrial and agricultural activities. This will have a positive economic impact for the communities in these locations.

\section{SITE ASSESMENT}

The main crops produced in the northern region of Cameroon are cereals (Maize, Sorghum, and Rice), root and tuber crops (Cassava, Yam, Macabo, Sweet potatoes and other) can be found in the south-western, the eastern and the southern regions of Cameroon. This study focuses on BPP development using crops residues from cereals. The best place to develop such kind of activity in Cameroon is the northern part. Energy conversion process of biomass encompasses different stages from the collection of residues to the production of energy as shown in Figure 1.

Installations of BPPs will be considered in four different regions because of their agricultural potentials: Mayo-Rey, Mayo-Louti, Faro, and Benue. The production of agricultural residues in the northern part of Cameroon is essentially ba-

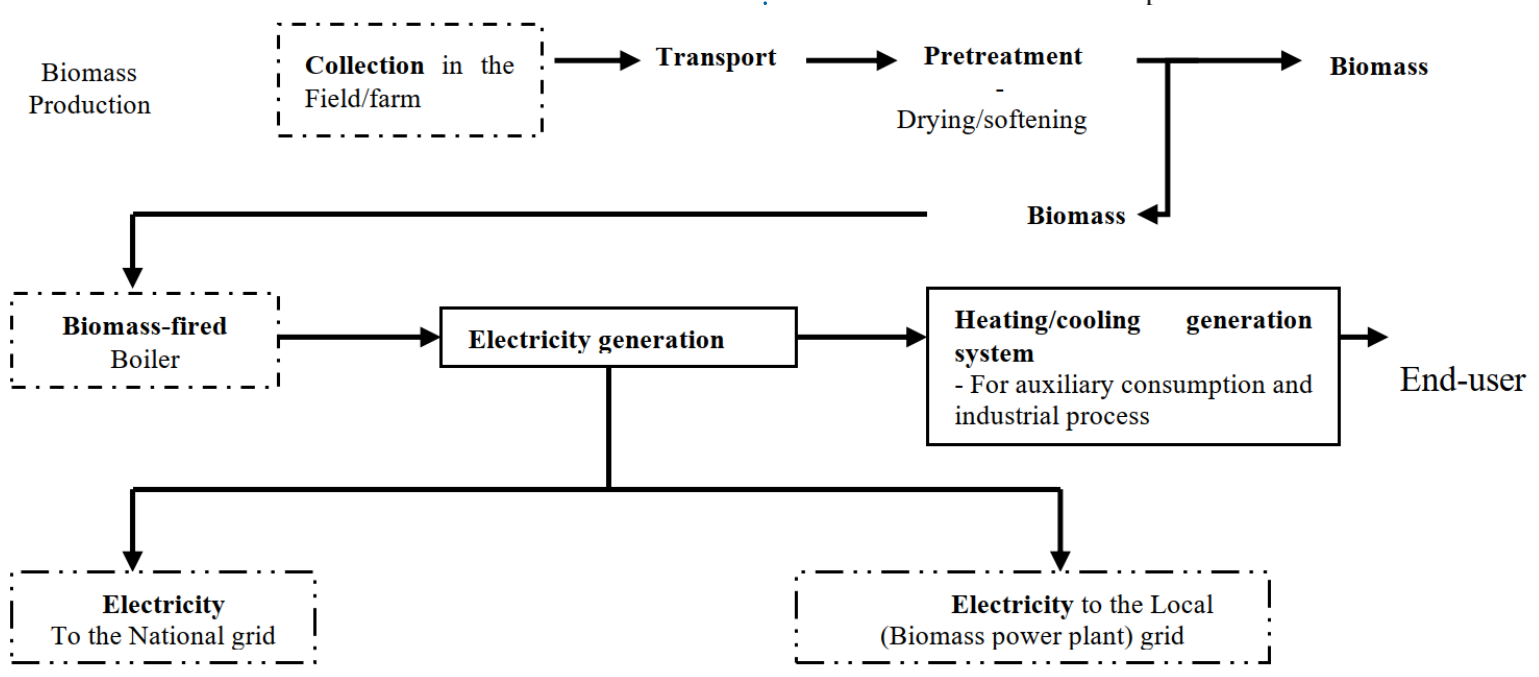

Fig. 1. Processes of agricultural residues for biomass power plants. 
Table 1. Energy potential from maize and sorghum crops residues in the northern Cameroon [15-18]

\begin{tabular}{|c|c|c|}
\hline Item & Number & Note \\
\hline $\begin{array}{l}\text { Maize area (ha) } \\
\text { Sorghum area (ha) }\end{array}$ & $\begin{array}{l}218864.21 \\
1151417.00\end{array}$ & Agriculture statistics (North) \\
\hline $\begin{array}{l}\text { Maize output in } 2016 \text { (ton) } \\
\text { Sorghum output in } 2016 \text { (ton) }\end{array}$ & $\begin{array}{l}756216 \\
1303581\end{array}$ & Agriculture statistics (North) \\
\hline $\begin{array}{l}\text { Maize Output per } \mathrm{Mu} \\
\text { Sorghum Output per } \mathrm{Mu}\end{array}$ & $\begin{array}{l}230 \mathrm{~kg} / \mathrm{Mu} \\
75.5 \mathrm{~kg} / \mathrm{Mu}\end{array}$ & Agriculture statistics \\
\hline $\begin{array}{l}\text { Residue - to -Product ratio (RPR) for Maize } \\
\text { Residue - to -Product ratio (RPR) for Sorghum }\end{array}$ & $\begin{array}{l}5.0: 1 \\
4.7: 1\end{array}$ & $\begin{array}{l}\text { Depending on fertilization, Crop variety and water } \\
\text { content (humidity) of the stalks. }\end{array}$ \\
\hline Residue Yield according to field study & & RPR $\quad 6.7: 1$ \\
\hline Residue Yield according to site investigation/stalk & $\begin{array}{l}3.45 / \text { ha } \\
1.13 / \text { ha }\end{array}$ & $\begin{array}{ll}\text { RPR } & 1.5: 1 \\
\text { RPR } & 2.62: 1\end{array}$ \\
\hline $\begin{array}{l}\text { The total amount of available maize stalk biomass at country } \\
\text { level could achieve (dry ton). } \\
\text { The total amount of available sorghum stalk biomass at } \\
\text { country level could achieve (dry ton) }\end{array}$ & $\begin{array}{l}0.96 \mathrm{E}+06 \\
2.98 \mathrm{E}+06\end{array}$ & $\begin{array}{l}\text { Conservation scenario with an estimated dry residue } \\
\text { yield of }--\mathrm{kg} / \mathrm{Mu} ; 1 \mathrm{ha}=15 \mathrm{Mu} \\
\qquad 2.59 / \mathrm{ha} \quad-173 \mathrm{~kg} / \mathrm{Mu}\end{array}$ \\
\hline Estimated energy potential & $\begin{array}{l}\text { 331.15 GWh } \\
\text { 1098.9 GWh }\end{array}$ & $\begin{array}{l}2.28 t / M W h \\
1.18 t / M W h\end{array}$ \\
\hline Biomass demand of neighboring town for 4.4TWh (dry ton) & $\begin{array}{l}2.82 E+06 \\
8.73 E+06\end{array}$ & 2.62 of sorghum stalk production \\
\hline Biomass market fraction for neighboring BPP & -. & $\begin{array}{l}\text { On site investigation at } 15 \text { collection points ( } 1 \text { per } \\
\text { department). }\end{array}$ \\
\hline BPP Capacity & $312 \mathrm{MW}$ & 4583.5hour \\
\hline
\end{tabular}

Table 2. Technical parameters for six locations in the northern part of Cameroon [19,20]

\begin{tabular}{|c|c|c|c|c|c|c|}
\hline \multirow[t]{2}{*}{ Parameter } & \multicolumn{6}{|c|}{ Locations } \\
\hline & Poli & Bouki & Vaimba & Toroua & Tcheboa & Adoumre \\
\hline $\begin{array}{l}\text { Average household energy } \\
\text { consumption (kWh/month) }\end{array}$ & 226.2 & 226.2 & 212.2 & 201.2 & 206.7 & 198.7 \\
\hline Number of houses & 82879 & 86237 & 97441 & 98880 & 94234 & 105925 \\
\hline Feedstock type & Maize/sorghum & Maize & Maize/sorghum & Sorghum & Sorghum & Sorghum \\
\hline
\end{tabular}

sed on the maize and sorghum harvests grouped in Table 1. The population of the northern Cameroon is estimated to be 7,532,312 peoples with 1,641,122 modern households. Their annual electricity consumption is about $2.69 \mathrm{MWh} /$ household/year. The total energy demand of the northern Cameroon is approximately $4.42 \mathrm{TWh} /$ year while the southern provinces have an energy demand estimated at $1.59 \mathrm{TWh} /$ year. Figure 2 presents the location of BPPs in six different municipalities of the northern provinces: Torua, Bouki, Vaimba, Adoumre, Poli, and Tcheboa. These points can deserve energy to the northern region due to their strategic position. The crops residues can be easily transported to Faro through neighbouring department which we make feedstock available continually. The majority of sorghum harvests are located in the city of Benue because it is the main collection point for the crops coming from the far North. It is important to note that the cost of crop residues is related to collection and transportation inter-urban activities. These costs are taken into account assessment distance between the collection point and the site of operation. The municipalities of Tcheboa, Benue and Faro are the collection and delivery points for sorghum and maize residues. Thus, the transport of these crop residues to the municipality of Tcheboa is estimated at 1.63 Million ton is also taken into account in the assessment of transport cost to the various municipalities. The Municipality of Poli will collect and transport maize residues from cities in the Adamawa region. Thus, the transport of these residues to this municipality is estimated at $249 \times 10^{3}$ tons and taken into account in the assessment of transport cost to the various municipalities.

Installations of biomass thermal power plants are considered in the municipalities of Poli and Bouki in the Faro Department, Vaimba in the Mayo-Rey Department and Toroua, Tcheboa, and Adoumre in the Benue department. Table 2 shows the monthly energy consumptions and feedstock potential of the locations. Actually, the monthly energy consumption of a household varies with seasons, but in this study, dry season is taken into consideration. Poli, Bouki, and Vaimba use residues from maize and sorghum crops while Toroua, Tcheboa, and Adoumre use only residues from sorghum crops. Availability of crop residues for each location are presented in Table 4. Also, feedstock prices are taken as $38 \mathrm{USD} /$ ton and $40 \mathrm{USD} /$ ton for maize and sorghum, respectively. The aim of this study is to supply energy for 565,596 households in these locations with an estimated annual energy production of $1.43 \mathrm{TWh}$.

\section{SYSTEM DESCRIPTION AND METHODOLOGY}

\subsection{System Description}

The system used for this study consists to combine an open cycle able to generate electricity, a steam extraction system 


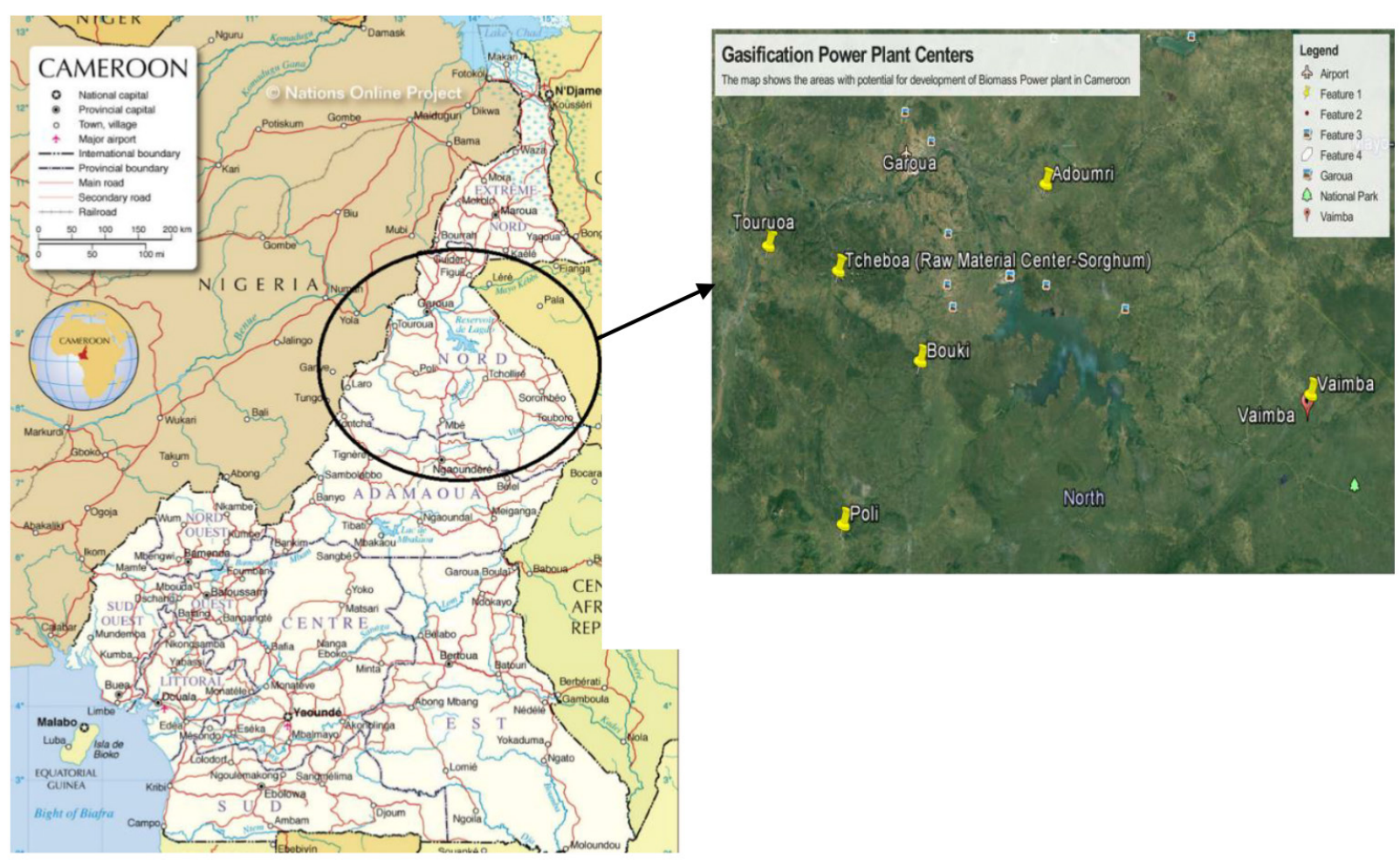

Fig. 2. Main collection points for dry residues in the northern Cameroon

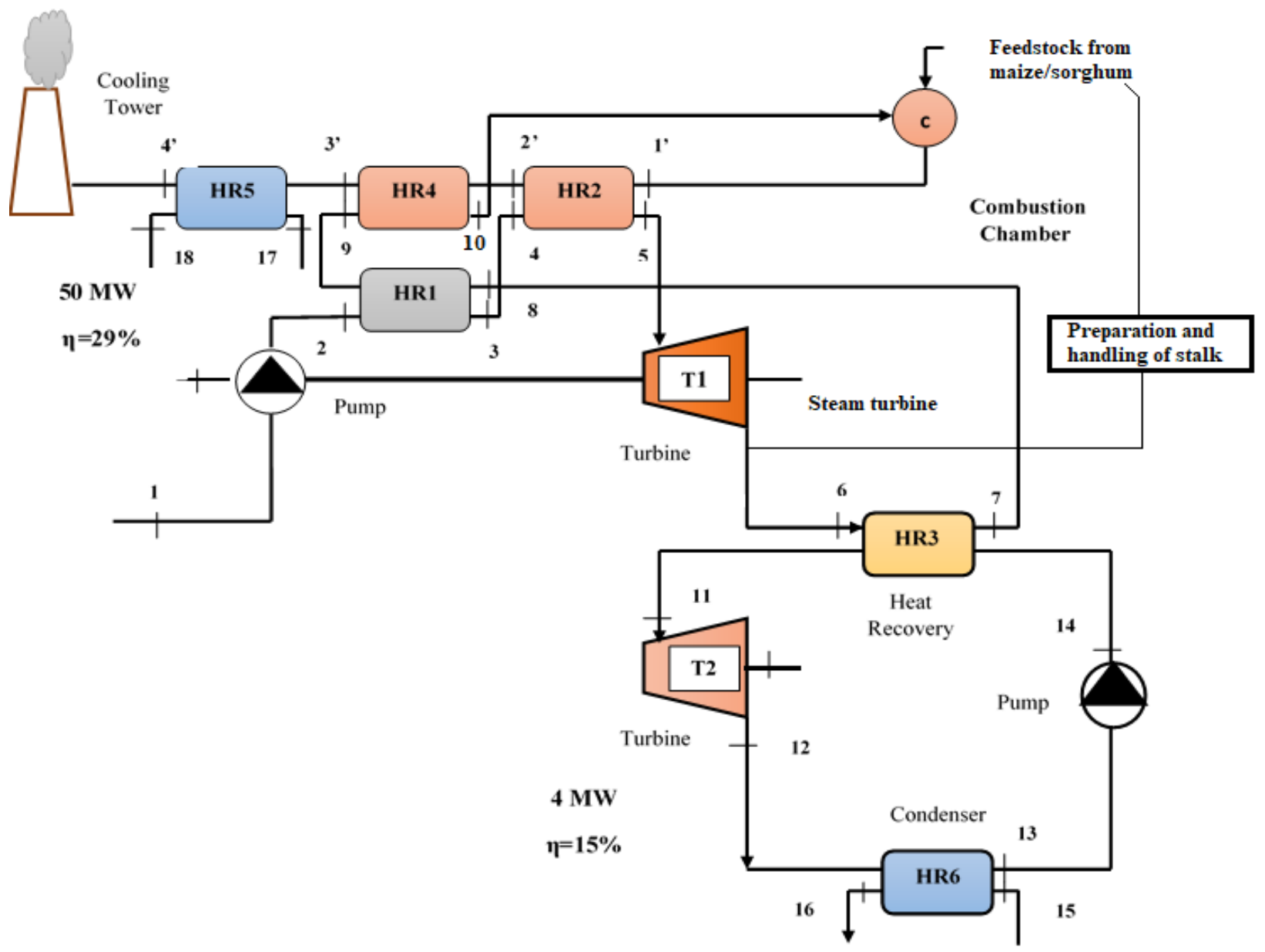

Fig. 3. Schematic of the biomass power plant 
which supply heat to dry the residues issue from agricultural activities (maize and sorghum) during the pre-treatment processes and an Organic Rankine Cycle (ORC) that converts low-temperature heat into electricity as shown in Figure 3.

ORC is connected to 5 turbines with $10 \mathrm{MW}$ capacity each one. The mass flow of the exhausted water steam from the turbines is drained towards the heat recovery, HR3. The R245fa is used as organic fluid in the ORC, while working fluid in the open cycle is steam. This fluid recuperates the heat from the top cycle (steam Rankine cycle) through regenerators, HR1, HR2. Part of the steam exhausted from the turbines is used for the processing of agricultural residues into feedstock. On the other hand, the steam generation system in this study will remain the same for a biomass fuel flow between $59.75 \mathrm{ton} / \mathrm{h}$ and $55.64 \mathrm{ton} / \mathrm{h}$.

\subsection{Methodology and Approach}

The methodology can be summarized as Figure 4. It will require several evaluation criteria, which can be classified as follow:

1. Technical evaluation: Efficiencies of main components of the BPP as a steam/gas turbine, a biomass boiler, a condenser, an electrical subsystem for transformation, and crop residues pre-treatment subsystem.

2. Financial evaluation: Levelized Cost of Electricity
(LCOE) and Payback Period (PBP).

3. Environmental evaluation: Savings of feedstocks and land usages.

The presented criteria of evaluation include main parameters related to sensitivity analysis, in order to show the effectiveness of the BPP compared to a power station in the rural area. The conversion process of crop residues to biomass will take place in the area close to the farm, in the biomass feedstock storage. However, the collection and pre-treatment processes of crop residues will be considered as variables depending on annual production and season duration. Expenditure for environment protection and social life will be considered as values during this study. The first will be considered as a fixed value and the second as a parametric value lied to the price of $\mathrm{tCO}_{2} / \mathrm{MWh}$. The technical evaluation based on energy analysis and environmental evaluation is done by using MATLAB and MS Excel softwares. Economic evaluation for obtaining levelized cost of electricity (LCOE), internal rate of return (IRR), net present value (NPV) and payback period of biomass power plant for the selected locations is conducted by the help of MS Excel software.

\section{TECHNO-ECONOMIC ANALYSIS}

This part of our study presents technical and economic (techno-economic) parameters, and taken assumptions used to estimate the BPP size in order to meet the energy demand required by the districts and the surrounding cities. Main

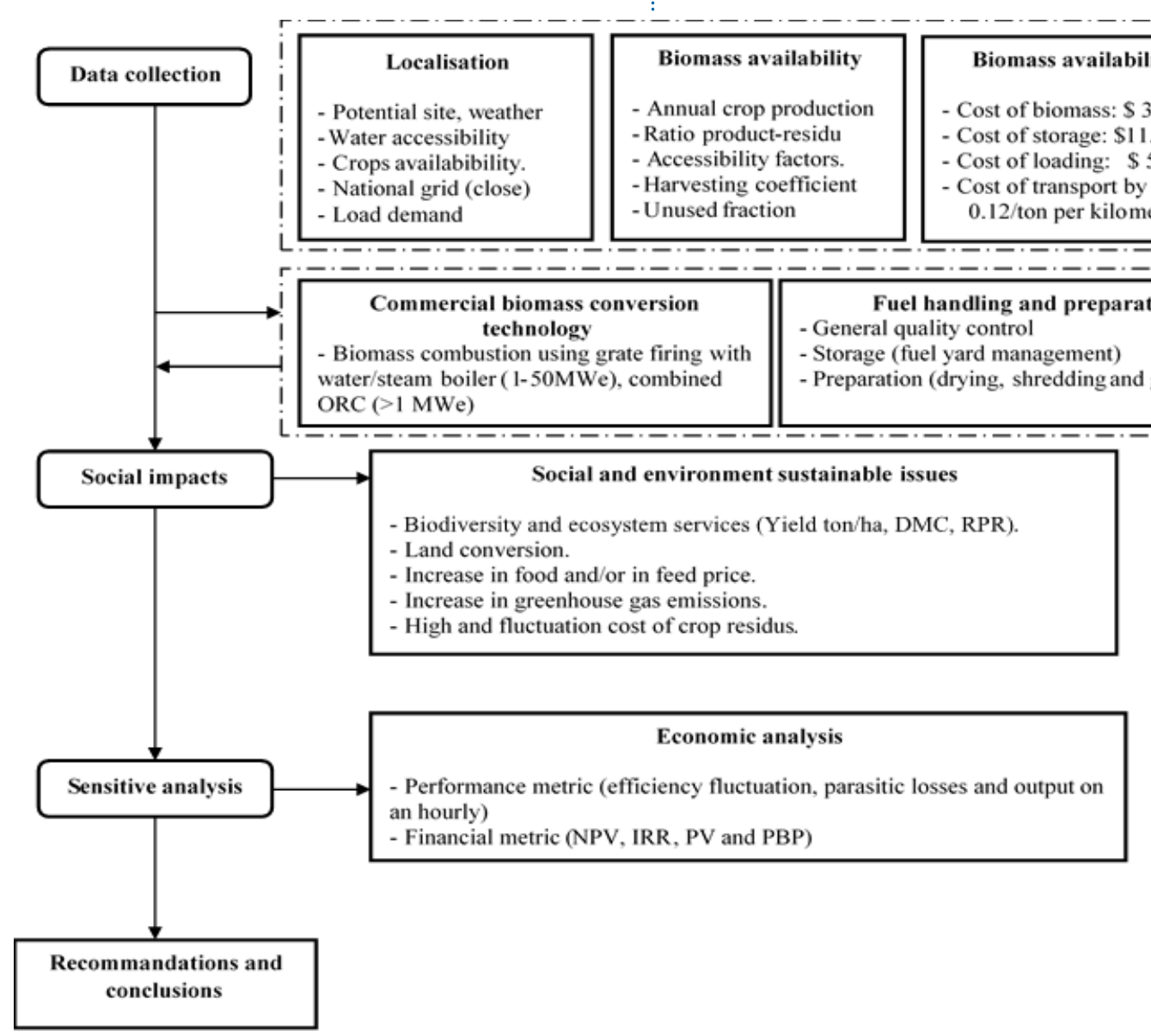

Fig. 4. Determination of main site criteria 
parameters and assumptions are listed as below:

- The boilers have an unburned carbon loss of 3.5\% and the fluidized bed combustor (FBC) technology has an unburned fuel loss of $0.25 \%$ [19].

- The steam temperature for the FBCs is $454^{\circ} \mathrm{C}$ and the pressure is around 55 bar [19].

- The fluidized bed combustor will operate with $20 \%$ excess air.

- The input combustion air temperature is $26.6^{\circ} \mathrm{C}$ and the flue gas temperature is $198.9^{\circ} \mathrm{C}$ [19].

- The heating system will be used for crop residues pre-treatment to improve feedstock's quality, but the expenditure lied to dry system acquisition and recovered money from energy saving during drying process are not considered in this feasibility. Further, this system may be used for food conservation after the seasonal harvest.

- The capital expenditure of the BPPs is taken as 3\% for the first 10 years, and it becomes $4 \%$ thereafter. During the first 4 years, the feedstock price will remain constant, and after this period, it will start to increase $4.1 \%$ each year.

- Annual energy consumption of households in the northern part of Cameroon is assumed to be 1.42 TWh.

\subsection{Energy analysis}

Generally, the lower heating value (LHV) is adjusted to the higher heating value (HHV) of the fuel under boiler conditions. The available biomass is obtained from maize and sorghum farms, which produce the raw waste (stalk). Then, they are burned in the same boiler separately to produce the necessary heat to run a turbine. The annual mass of biomass is estimated based on the plant size, the heating value of the available biomass fuels. The required mass varies with moisture content and power plant efficiency.

The following equation gives the value of the HHV when the value of the LHV is known [1].

$$
\mathrm{HHV}=L H V+10.30 \times\left(H_{2}-8.94\right)
$$

The most important efficiency losses in the studied system are dry flue gas losses, moisture in fuel, latent heat, unburned fuel, and radiation and miscellaneous. Then, the amount of useful heat can be calculated using the following equation [3].

$$
\begin{aligned}
& \dot{Q}=\dot{b} \times H H V \times\left(100-\left(e_{\text {moisture }}+e_{\text {manuf }}+e_{\text {rad }}\right.\right. \\
& \left.\left.+e_{\text {unb. Carb }}+e_{\text {latent heat }}+e_{\text {fuel moist }}\right)\right)
\end{aligned}
$$

where, $\dot{b}$ is the dry biomass feeding rate. The mass flow rate of steam can be determined by using equation [4].

$$
\dot{m}_{\text {steam }}=\frac{\dot{Q}}{H_{\text {steam }}}
$$

where, $H_{\text {steam }}$ is the enthalpy of the steam. The heat supplied to the turbine in the form of steam is given as below [4]:

$$
o_{n e t}=\eta \times \dot{Q} \times t
$$

The load that a power plant requires to operate itself is called parasitic loss, then gross energy output of power plant can be determined by using the following equation [6].

$$
O_{\text {net }}=O_{\text {gross }} \times p
$$

The gross and net heat rate are important indications of plant performance. They can be calculated as:

$$
\begin{aligned}
& H R_{\text {gross }}=\frac{H H V \times \dot{b}}{\dot{O}} \\
& H R_{\text {gross }}=\frac{L H V \times \dot{b}}{\dot{0}}
\end{aligned}
$$

The calculation of heat rate value conduct to the thermal efficiency, which is expressed by:

$$
\begin{aligned}
& \eta_{t h, H H V}=\frac{341.23}{H R_{\text {gross }}} \\
& \eta_{t h, L H V}=\frac{341.23}{H R_{\text {net }}}
\end{aligned}
$$

The capacity factor of the thermal power plant can be expressed using the following equation.

$$
\mathrm{CF}=\frac{\dot{o}}{C_{d e s} \times t}
$$

\subsection{Economic analysis}

The annual electricity production (AEP) of the BPP depends on the type of technology and the feedstock characteristics used to run the plant. For the $\mathrm{i}^{\mathrm{th}}$ year, annual electricity production can be calculated as below:

$$
E_{i}=E_{0}\left(100-\frac{D R}{100}\right)^{i}
$$

where $D R$ and $E_{0}$ are the degradation factor and the electricity production at the beginning.

Discounted cash flow (DCF) of any investment can be found by using Eq. 12:

$$
\mathrm{DCF}=\left(\frac{\text { Real FiT }+ \text { Bonus }}{\delta^{n}}\right) \times E_{i} \times\left(1-\frac{1}{(1+\delta)^{n}}\right)
$$

The weight average cost of the capital can be calculated using a proportionate interest and equity rates. However, in this study, it is considered that the owner will finance BPP without using any loan credit. The real Feed -in - Tariff (FiT) is taken as 13.8 USD Cents/kWh, which is valid for less than 100 MW. The FiT rates are shown in Table 3. Specific bonus tariffs are also provided for domestic technologies and environment consideration. In this study, fluidized bed combustor and a use of mechanical accessories for a steam production system that collects the crop residues on the boiler increase the sale price of electricity with 2.4USDcent/ $\mathrm{kWh}$ and 1.8USDcent/kWh, respectively. Therefore, Eq. 12 becomes as below:

$\mathrm{DCF}=($ Real FiT + Bonus $) \times E_{i}$ 
Table 3. Feed-in-Tariff rates for biomass power plants in Cameroon, 2014 [17].

\begin{tabular}{|l|l|}
\hline $\begin{array}{l}\text { Biomass power plant - based on the produc- } \\
\text { tion facility }\end{array}$ & $\begin{array}{l}\text { Domestic Contribution } \\
\text { (USDcent/kWh) }\end{array}$ \\
\hline 1- Combustor of fluidized bed & 2.4 \\
\hline 2- Utilization of crop residues & 0.6 \\
\hline 3- Transportation and storage system & 0.6 \\
\hline 4- Integration and mechanic structures & 0.6 \\
\hline $\begin{array}{l}\text { Production facility based on renewable } \\
\text { energy }\end{array}$ & $\begin{array}{l}\text { Feed-in-Tariff Prices (USD- } \\
\text { cent/kWh) }\end{array}$ \\
\hline Biomass power system based on facility & 13.8 \\
\hline
\end{tabular}

Gross profit margin is calculated by deducting the cost of goods sold (electricity generation cost) from the revenue generated by the sale of the energy produced. The earnings before interest and tax (EBIT) are calculated by deducting the operating cost from the gross profit. After interest and tax (EAIT) are calculated by adding the good production cost (subvention) related to $\mathrm{tCO}_{2}$ produced per unit of MWh generated, in order to protect. This kind of incentive come from financial institutions encouraging project which promote the use of clean energies or taxes collected from commercial thermal power plant using fossil resources such as coal, gas and others. In the developing countries taxes are estimated at 4.4 USD and above per $\mathrm{tCO}_{2}$ produced using national certified taxation (CERTAX) document (7.14 per MWh). The EAIT had been used in the techno-economic analysis to determinate abatement of the payback period. The value of the return of the investment (ROI) is one of the best indicators for the investor

$$
\begin{aligned}
& \text { EBIT }=(\text { GROSS PRFIT }- \text { DISCOUNTED OPEX }) \\
& \text { EAIT }=\text { EBIT }+ \text { Discounted CERTAX }
\end{aligned}
$$

Discounted CERTAX $=$ AEP $(\mathrm{MWh}) \times 7.14\left(\mathrm{tCO}_{2}\right) \times$ 4.397 (USD/ tCO $)$

$$
\mathrm{ROI}=\left(\frac{\sum_{i=1}^{n} \frac{E B I T_{i}}{(1+r)^{i}}}{\text { Real Inst. Cost }}\right)-1
$$

As explained above, net present value (NPV) is a very good indicator and has to be a positive value for a bankable project.

$$
\mathrm{NPV}=- \text { Real Inst. } \operatorname{Cost}+\sum_{i=1}^{n} \frac{E B I T_{i}}{(1+r)^{i}}
$$

In this study, discount rate value is assumed as $7 \%$ and it is considered that the project became full bankable when the IRR is more than $11 \%$ due to some inconvenient related to this new market (insurance, inspection, power purchased agreement (PPA) negotiation, rate of inflation in the countries etc.).

$$
\text { Real Inst. Cost }=\sum_{i=1}^{n} \frac{E B I T_{i}}{(1+I R R)^{i}}
$$

The calculation of levelized cost of energy (LCOE) is the main goal to carry out the Real FiT value.

$$
\mathrm{LCOE}_{\mathrm{i}}=\frac{\text { Real discount cost }(1+O M \cos t+T I R \cos t+\text { AMRcost })}{(\text { Annual Energy generated })_{m e}}(20)
$$

\section{RESULTS AND DISCUSSION}

Main results obtained from technical and economic analyses (techno-economic analysis) are given in Table 4. The total installed capacity of the biomass power plant (BPP) is estimated to be $270 \mathrm{MW}$ and annual energy production is calculated to be $1.27 \mathrm{TWh} /$ year as seen in Table 5 . This table gives an estimated value of the bonus achieved for each MWh produced with the preservation of the environment (51.4 USD/MWh). The economic analysis of the BPP lets to the determination of these values, internal rate of return (IRR), net present value (NPV) for the equal payback period. Table 9 presents a cash flow analysis of the BPP plant with CER/Tax-Carbon bonus. It has been done in order to determine if a loan could be beneficial for a private investor in such project. The value of IRR is closely related to the annual income of the BPP and the initial investment. When the project is done without obtaining a loan from a financial institution, the IRR value is greater than the required minimum value (usually greater than 10\%) for the BPP project's bankability study. On the other hand, if the project is financed by a financial institution, the value of the IRR decreases considerably.

\begin{tabular}{l} 
Table 4: Main results of technical and economic analyses of BPPs. \\
\begin{tabular}{|l|l|}
\hline Capacity & $270 \mathrm{MW}$ \\
\hline Annual Energy Production & 1.27 TWh/year \\
\hline Total Investment & 874.45 Million USD \\
\hline Energy needs in North-Cameroon & 4.4 TWh/year \\
\hline Biomass fuel Cost & 103.08 Million USD \\
\hline CER/TAX & 65.51 Million USD \\
\hline PBP (Year) & 4.69 years \\
\hline IRR & $20.75 \%$ \\
\hline NPV & 1.04 Billion USD \\
\hline & Without CER/TAX \\
\hline PBP (Year) & 7.27 years \\
\hline IRR & $12.45 \%$ \\
\hline NPV & 335.91 Million USD \\
\hline LCOE & 94 USD/MWh \\
\hline
\end{tabular} \\
\hline
\end{tabular}

The gross profit margin is calculated by deducting the cost of goods production (electricity generation cost) from the revenue generated by the sale of the energy produced. The earnings before interest and tax (EBIT) are calculated by deducting the operating cost from the gross profit. After interest and tax (EAIT) are calculated by adding CER/Tax (1MWh per $7.14 \mathrm{tCO}_{2}$ and $1 \mathrm{tCO}_{2} 7.2 \mathrm{USD}$ ). The annual cash flows are discounted to calculate NPV of the system. The importance factors impacting directly in the technical feasibility of biomass is an available amount of biomass feedstock for the studied power plant. Table 5 shows a total theoretical potential of electricity generation per biomass residues type. The practical potential is lower than this due to technical consideration such as a part of the agriculture residues which is burned in the field after seasonal harvest. The value of Annual Operating Expenditure (AOE) depends on the annual production of electricity, annual fixed costs of operating and maintenance (O\&M) and the duration of intervention on the site for the works not subcontracted with 
an O\&M team. Generally, the value of the discount rate is more than $8 \%$ according to Malek et al. [8]. For this study, we used the value $12 \%$ as the value of the discount rate to cover the difficulties related to the study bankability because the feasibility studies consider an average value of biomass price mentioned in Table 5. This value has an impact on the annual electricity production and LCOE. Furthermore, LCOE is highly sensitive to feedstock price and discount. Table 5 presents installation and system costs of BPPs in the six locations. We can find detailed information related to energy production and biomass fuel cost for each city. Biomass fuel costs are divided between storage, variable cost and fixed cost of transportation for dry crop residues. Then, the value fixed for transportation of a dry ton of crop residues is estimated at 10 USD. We add to this value 6 USD cent per kilometer travelled. For the plant, the annual energy production varies according to biomass availability. The installation cost per $\mathrm{kW}$ of the BPP is fixed. The contingency of the BPP construction is estimated at $8 \%$ of the total direct cost. Thus, the investment cost varies substantially with used technologies, operating conditions and types of feedstocks. The biomass fuel is an important factor in biomass power generation. The physical properties of feedstock can affect plant efficiencies and environment in the locality. The average nominal and real LCOE are between 6.98 USDcent/ kWh and 12.93 USDcent/kWh. As shown in Table 5, BPPs of

Table 5. Overall performance outputs of biomass power plants

\begin{tabular}{|c|c|c|c|c|c|c|c|c|c|c|c|c|}
\hline Performance & Output data & Unit & $\begin{array}{l}\text { Specific } \\
\text { Value }\end{array}$ & \multicolumn{2}{|c|}{ Poli } & \multicolumn{2}{|c|}{ Bouki } & \multicolumn{2}{|c|}{ Rey } & Toroua & Amdoumre & Tcheboa \\
\hline \multirow{2}{*}{ Y. B. AVAILABLE } & Stalk & \multirow[b]{2}{*}{ ton } & \multirow[b]{2}{*}{ - } & \multicolumn{2}{|c|}{$15 \mathrm{~km}$} & \multicolumn{2}{|c|}{$90 \mathrm{~km}$} & \multicolumn{2}{|c|}{$210 \mathrm{~km}$} & $90 \mathrm{~km}$ & $75 \mathrm{~km}$ & $20 \mathrm{~km}$ \\
\hline & Sorghum Maize & & & 228361 & 147849 & 182689 & 182378 & 345166 & 114390 & 282763 & 277456 & 298745 \\
\hline \multirow[t]{13}{*}{ TECHNICAL } & Plant eff. ( $\eta)$ & $\%$ & - & & & & & & & & & \\
\hline & Global losses & & & 0.2767 & 0.3015 & 0.2767 & 0.3015 & 0.2767 & 0.3015 & 0.2767 & 0.2767 & 0.2767 \\
\hline & $\begin{array}{l}\text { Annual operating } \\
\text { hours }\end{array}$ & hours & & 5000 & - & 5000 & - & 5000 & - & 5000 & 5000 & 5000 \\
\hline & Annual. production & GWh/yr. & & 112.049 & 90.948 & 138.153 & 72.778 & 137.331 & 86.637 & 214.164 & 212.268 & 210.146 \\
\hline & Plant capacity & MW & & 23.43 & 18.4 & 30.48 & 15.17 & 30.72 & 18.54 & 45.22 & 44.77 & 43.17 \\
\hline & Parasitic losses & $\%$ & & 4.9 & - & 4.9 & - & 4.9 & - & 4.9 & 4.9 & 4.9 \\
\hline & $\begin{array}{l}\text { Annual gross pro- } \\
\text { duction }\end{array}$ & GWh & & 117.822 & 95.634 & 145.27 & 76.528 & 144.41 & 91.101 & 225.207 & 223.205 & 220.97 \\
\hline & P.Capacity gross & MW & & 24.64 & 19.348 & 32.05 & 15.95 & 32.31 & 19.51 & 47.55 & 47.08 & 45.40 \\
\hline & Heat Rate net & MMBtu /M & १Wh & 8.66 & 8.958 & 8.2127 & 8.6825 & 8.4678 & 8.1011 & 8.5821 & 9.1587 & 8.8201 \\
\hline & Av. Boiler eff. & & & 0.96 & - & 0.96 & - & 0.96 & - & 0.96 & 0.96 & 0.96 \\
\hline & Thermal eff., HHV & $\%$ & & 36.07 & 34.72 & 38.03 & 35.82 & 36.89 & 38.40 & 36.41 & 34.10 & 35.41 \\
\hline & Thermal eff., LHV & $\%$ & & 39.40 & 38.09 & 41.55 & 39.30 & 40.29 & 42.12 & 39.76 & 37.25 & 38.68 \\
\hline & Capacity factor, CF & $\%$ & & 91.54 & 91.14 & 91.52 & 91.18 & 91.45 & 92.04 & 91.56 & 91.59 & 91.58 \\
\hline FINANCIAL & BFC per ton & USD/dt & USD per ton & 38 & 40 & 38 & 40 & 38 & 40 & 40 & 40 & 40 \\
\hline [In US Dollar] & BFC of available B. & Million & - & 8.68 & 5.92 & 6.95 & 7.29 & 13.12 & 4.58 & 11.31 & 11.10 & 11.95 \\
\hline & $\begin{array}{l}\text { Dist. Fixed deliv. } \\
\text { cost }\end{array}$ & Million & 10USD/ton & 2.29 & 1.48 & 1.83 & 1.82 & 3.45 & 1.14 & 2.83 & 2.78 & 2.99 \\
\hline & $\begin{array}{l}\text { Dist. Variable del. } \\
\text { cost }\end{array}$ & Million & $\begin{array}{l}\text { 6USDcent/ } \\
\text { ton }\end{array}$ & 0.20 & 0.13 & 0.99 & 0.98 & 0.44 & 0.14 & 0.14 & 1.25 & 0.36 \\
\hline & Biomass Fuel cost & Million & - & 10.96 & 7.39 & 8.77 & 9.12 & 16.57 & 5.72 & 14.14 & 15.12 & 15.29 \\
\hline & D. Cap. Costs (DCC) & Million & $\begin{array}{l}2765 \text { USD/ } \\
k W\end{array}$ & 67.17 & 52.75 & 87.38 & 43.48 & 88.08 & 53.19 & 129.64 & 128.36 & 123.77 \\
\hline & $\begin{array}{l}\text { Total inst. cost } \\
\text { (TIC) }\end{array}$ & Million & $\begin{array}{l}\text { 3155USD/ } \\
\text { kW }\end{array}$ & 75.91 & 59.60 & 98.74 & 49.14 & 99.54 & 60.11 & 146.49 & 145.04 & 139.87 \\
\hline & Av. cost per kWh & Million & 15 USDcents & 16.81 & 13.64 & 20.72 & 10.92 & 12.99 & 20.60 & 32.12 & 31.84 & 31.52 \\
\hline & Discount rate & $\%$ & 8 & - & - & - & - & - & - & - & - & - \\
\hline & $\begin{array}{l}\text { CER/TAX (USD/ } \\
\text { MWh) }\end{array}$ & Million & 51.4 & 5.76 & 4.67 & 7.10 & 3.74 & 5.76 & 4.45 & 11.01 & 10.91 & 10.80 \\
\hline & IRR & $\%$ & & 19.19 & 23.01 & 23.37 & 15.3 & 16.56 & 23.83 & 23.36 & 22.77 & 23.02 \\
\hline & NPV & Million & & 78.21 & 86.24 & 146.46 & 32.47 & 79.19 & 92.12 & 214.19 & 203.79 & 202.22 \\
\hline & PBP & Year & & 5.08 & 4.29 & 4.22 & 6.25 & 5.87 & 4.17 & 4.2 & 4.31 & 4.29 \\
\hline & LCOE & $\begin{array}{l}\text { USDcent/ } \\
\text { kW }\end{array}$ & & 10.47 & 8.41 & 6.81 & 12.93 & 11.91 & 6.98 & 7.66 & 8.04 & 8.20 \\
\hline WITHOUT CER/T, & TAX & & & & & & & & & & & \\
\hline & NPV & Million & & 177.10 & 36.34 & 70.65 & - & - & 44.58 & 96.68 & 87.33 & 86.91 \\
\hline & IRR & $\%$ & & 10.73 & 14.70 & 15.80 & $>12 \mathrm{Y}$ & $>10 \mathrm{Y}$ & 16.05 & 15.32 & 14.71 & 14.83 \\
\hline & PBP & Year & & 8.40 & 6.51 & 6.11 & - & - & 6.01 & 6.25 & 6.48 & 6.46 \\
\hline
\end{tabular}


Vaimba and Bouki have the best LCOE values for a payback period estimated as 6.11 and 6.01 years respectively (with CER / TAX application 4.22 and 4.17years). Furthermore, the BPPs in the city of Benue have a LCOE between 7.66 USDcent $/ \mathrm{kWh}$ and $8.20 \mathrm{USD}$ cent $/ \mathrm{kWh}$, for a payback period between 6.25 and 6.46 years (between 4.2 and 4.31 years with CER/TAX application). While the BPPs developed in the municipalities of Poli have LCOE values between 10.47 USDcent $/ \mathrm{kWh}$ and 8.41 USDcent $/ \mathrm{kWh}$, for a payback period between 8.40 and 6.51 years (between 5.08 and 4.29 years with CER/TAX application).

Main results of the economic analysis are shown in Figure 5. The estimated installed cost per $\mathrm{kW}$ is estimated as 3087 USD $/ \mathrm{kW}$. Installations of the BPPs in the municipalities of Bouki and Vaimba using both maize and sorghum seem to be not bankable without CER/TAX incomes. The use of crop residues from maize and sorghum to run the BPPs in Bouki and Vaimba municipalities is not profitable according to economic parameters found during the financial analysis. The use of residues from Sorghum and maize for BPP of these municipalities Vaimba and Bouki respectively do not allow a reliable return on investment given to the value of LCOE estimated as 12.93 USDcent/kWh and 11.91 USDcent $/ \mathrm{kWh}$, respectively.
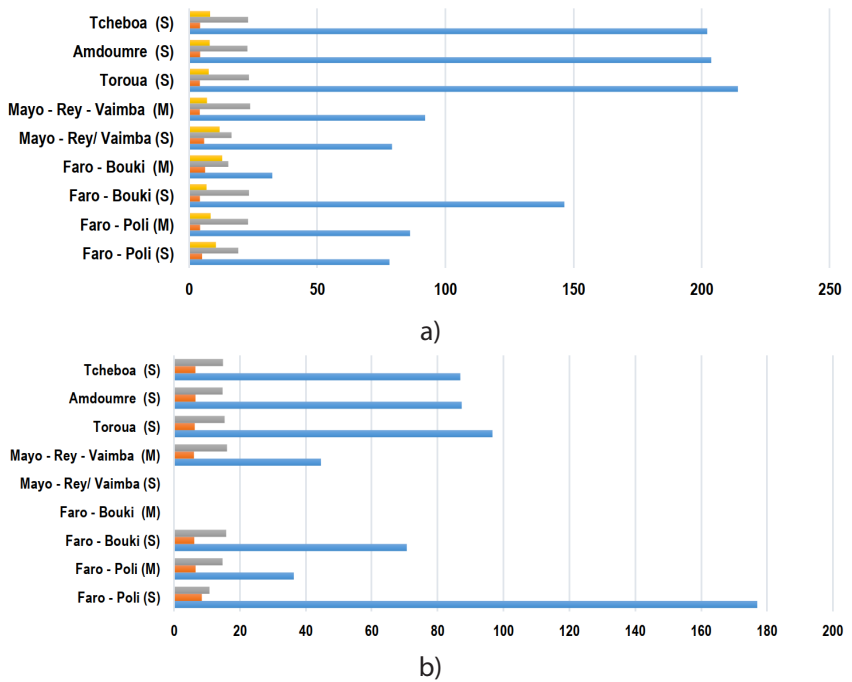

Fig. 5. Comparison of economic parameters of the Biomass Power Plants developed for different locations a) with CER/TAX b) without CER/TAX.

\section{CONCLUSION}

Using biomass power plants for electricity generation and heat production has a positive impact on both environmental, social life and economy. For the economic impact, the amount of tone of fossil substituted by biomass in ton per year can be evaluated. The reduction of the biomass cost can be done by creating a biomass market for electricity generation and biomass supply chain including private company already dealing in this sector. The biomass fuel from maize will be used to run the studied BPP of the municipality of Bouki does not allow the bankability of this project. As a result, the volume of feedstock will be transferred to the BPP of the municipality of Vaimba. Then it will work entirely with biomass fuel from maize. It will be the same for the BPP of the municipality of Bouki which will receive biomass fuel from sorghum previously intended for the municipality of Vaimba. On the other hand, the use of biomass fuel from sorghum in the Poli municipality needs to be evaluated again because the cost of transport and other factors have a considerable impact on the project's bankability calculations. In this study, we also focused on the effects of differences in order to predict a payback period of the BPP. The application of the CER / TAX provides an estimated average payback period of 4.69 years, which is 2.6 years less than forecast for the BPP developed without the application of CER/TAX. As a result, the CER/TAX application for projects developed in the North Cameroon region has a positive impact on the investment return calculations. This can revive the debates on the evaluation of the Feed-in-tariff by the authorities of the electricity regulatory agency (ARSEL) while allowing private investors to carry out those projects.

\section{REFERENCES}

[1] Inna S., Yvette J., Richard K., (2015). Energy Potential of Waste Derived from Some Food Crop Products in the Northern Part of Cameroon. International Journal of Energy and Power Engineering, 4: 342-352, DOI: 10.11648/j.jijepe.20150406.13

[2] Nfah E.M., Ngundam J.M., Tchinda R., (2007). Modeling of solar/ diesel/battery hybrid power systems for far-north Cameroon. Renewable Energy, 32: 832-844, DOI:10.1016/j.renene.2006.03.010

[3] Nkutchet M., (2004). L'Energie au Cameroun, Edition l'Harmattan.

[4] Ministère des Mines de l'Eau et de l'Energie, (1990). Plan Energétique National.

[5] Lighting Africa, (2012). Lighting Africa Policy Report Note - Cameroon. IFC and WB.

[6] Emmanuel N., (2009). Renewable Energies in West Africa: Cameroon country, GTZ Regional Report.

[7] Cheng S., Li Z., Gao R., Wang X., Mang H.P., (2014). Methodology development of evaluating agricultural biomass potential for biomass power plant in China, Energy Procedia, The 6th International Conference on Applied Energy-ICAE2014: 13 - 16.

[8] Nunes L.J.R., Matias J.C.O., Catalao J.P.S., (2017). Biomass in the generation of electricity in Portugal: A review, Renewable and Sustainable Energy Reviews, 71: 373-378,_DOI: 10.1016/j.rser.2016.12.067

[9] Malek A., Hasanuzzaman M., Rahim N. A., Al Turki Y. A., (2015). Techno-economic analysis and environmental impact assessment of a $10 \mathrm{MW}$ biomass-based power plant in Malaysia, Journal of Cleaner Production, 141:502-513, DOI: 10.1016/j.jclepro.2016.09.057 0959-6526

[10] Sampim T., Kokkaew N., Parnphumeesup P., (2017). Risk Management in Biomass Power Plants Using Fuel Switching Flexibility. International Conference on Alternative Energy in Developing Countries and Emerging Economies 2017, Bangkok. Thailand, Energy Procedia 138: 1099-1104.

[11] Gebreegziabher T., Oyedun O., Luk H.T., Lam Y.G., Zhang Y., Hui C.W., (2014). Design and optimization of biomass power plant, Chemical Engineering Research and Design, 92: 1412-1427, DOI: 10.1016/j.cherd.2014.04.013

[12] Kalina, J., (2017). Techno-economic assessment of small-scale integrated biomass gasification dual fuel combined cycle power plant, 
Energy, 141: 2499-2507.

[13] Abdelhady S., Borello D., Shaban A., (2018). Techno-economic assessment of biomass power plant fed with rice straw: Sensitivity and parametric analysis of the performance and the LCOE, Renewable Energy, 115:1026-1034, DOI: 10.1016/j.renene.2017.09.040.

[14] Ali U., Font-Palma C., Akram M., Elvis O.A., Derek B, Ingham D.B., (2017). Pourkashanian M.P., Comparative potential of natural gas, coal and biomass fired power plant with post - combustion $\mathrm{CO}_{2}$ capture and compression, International Journal of Greenhouse Gas Control, 63: 184-193.

[15] Ackom, E., (2010). Sustainability Standards for Canada's Bioethanol Industry, Biofuels, 8: 237-241, DOl: 10.4155/bfs.10.8

[16] Ackom E., Mabee W, Saddler J, Backgrounder, (2010). Major Environmental Criteria of Biofuel Sustainability, International Energy Agency (IEA) Bioenergy Task 39 Report.

[17] FAOSTAT 2014, (2014). Evaluation des resources forestières du Cameroun.

[18] Wirba A.V, Abdullahi Abubakar Mas'ud A.A., Muhammad-Sukki F., Ahmad S., Tahar R.M., Rahim R.A., A.B., Karim M.E., (2015). Renewable energy potentials in Cameroon: prospects and challenges. Renewable Energy; 76: 560-565_DOl:10.1080/23311916.2016.1167 990

[19] Fonjong, L.N., (2004). Changing fortunes of government policies and its implications on the applications of agricultural innovations in Cameroon, Nordic Journal of African Studies, 13: 13-29.

[20] http://www.invest.gov.tr/en-S/investmentguide/investorsguide/Pages/Incentives.aspx. Accessed on March 2018 